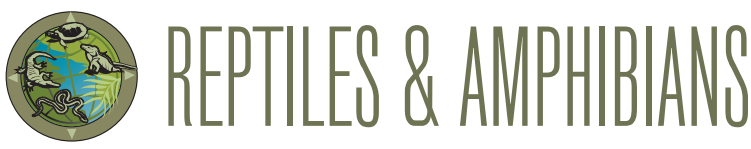

\title{
First Report of Predation by a Bright-rumped Attila (Attila spadiceus) on a Red-eyed Treefrog (Agalychnis callidryas) on the Peninsula de Osa, Costa Rica
}

\author{
Raby Nuñez Escalante ${ }^{1}$ and Dennis Atencio Valverde ${ }^{2}$ \\ 'Sierpe de Osa, Puntarenas, Costa Rica (sierpefrogs@gmail.com [corresponding author]) \\ ${ }^{2}$ Puerto Jimenez, Puntarenas, Costa Rica (osaphotography@outlook.com)
}

Crogs in the families Hylidae and Phyllomedusidae are frequent prey of many predators, including birds (e.g., Toledo et al. 2011). Many passerines and other birds in Neotropical forests are known to include these anurans in their diets (Stiles et al. 1989; Wetmore 1965, 1968, 1972; Wetmore et al. 1984).

Adult Red-eyed Treefrogs (Agalychnis callidryas) are nearly exclusively arboreal, although reproductive females seek out standing water on the ground from which to absorb moisture, which is used to hydrate internally maturing ova (Pyburn 1970). Few reports document predators of adult Red-eyed Treefrogs and most of what we know about the subject is based on the diets of potential predators (Savage 2002). Herein we describe what, to the best of our knowledge, is the first observation of predation on an adult Redeyed Treefrog by a Bright-rumped Attila (Attila spadiceus).
While photographing Spectacled Owls (Pulsatrix perspicillata) at $1050 \mathrm{~h}$ on 26 May 2021 in the La Perica Sloth Garden, Puerto Jimenez, Costa Rica ( $8^{\circ} 39^{\prime} 16.4^{\prime \prime N}$, 83²8'05.6"W; near sea level), when DAV saw a Brightrumped Attila on a nearby tree. As the bird flew to and perched on an exposed branch of a Guaitil Tree (Simira maxonii), we noticed its recently caught prey (Fig. 1). The bird was holding an $A$. callidryas by its legs and beat it against the branch for about 3 minutes before swallowing it. The bird then flew away and disappeared among the vegetation.

\section{Literature Cited}

Pyburn, W.F. 1970. Breeding Behavior of the Leaf-Frogs Phyllomedusa callidryas and Phyllomedusa dacnicolor in Mexico. Copeia 1970: 209-218. https://doi. org/10.2307/1441643.

Savage, J. M. 2002. The Amphibians and Reptiles of Costa Rica: A Herpetofauna Between Two Continents, Between Two Seas. University of Chicago Press,
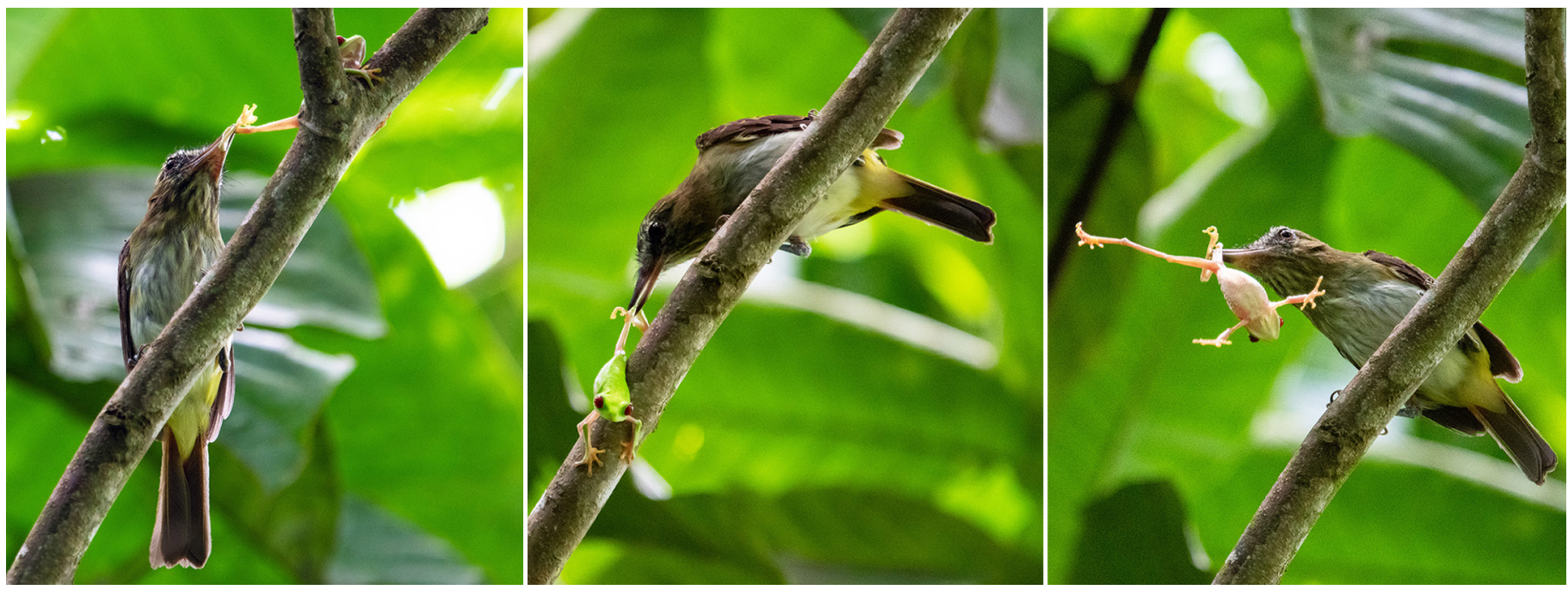

Fig. 1. A Bright-rumped Attila (Attila spadiceus) preying on an adult Red-eyed Treefrog (Agalychnis callidryas) on a Guaitil Tree (Simira maxonii) in La Perica Sloth Garden, Puerto Jimenez, Costa Rica. Photographs by Dennis Atencio Valverde. 
Chicago, Illinois, USA.

Stiles, F.G., A.F. Skutch, and D. Gardner. 1989. A Guide to the Birds of Costa Rica. Cornell University Press, Ithaca, New York, USA.

Toledo, L.F., I. Sazima, and C.F.B. Haddad. 2011. Behavioural defenses of anurans: an overview. Ethology Ecology \& Evolution 23: 1-25. https://doi.org/ 10.1080/03949370.2010.534321.

Wetmore, A. 1965. The Birds of the Republic of Panama. Part 1. Tinamidae (Tinamous) to Rynchopidae (Skimmers). Smithsonian Miscellaneous Collections, Volume 150. Smithsonian Institution Press, Washington, DC, USA.

Wetmore, A. 1968. The Birds of the Republic of Panama. Part 2. Columbidae
(Pigeons) to Picidae (Woodpeckers). Smithsonian Miscellaneous Collections, Volume 150. Smithsonian Institution Press, Washington, DC, USA.

Wetmore, A. 1972. The Birds of the Republic of Panama. Part 3. Passeriformes: Dendrocolaptidae (Woodcreepers) to Oxyruncidae (Sharpbills). Smithsonian Miscellaneous Collections, Volume 150. Smithsonian Institution Press, Washington, DC, USA.

Wetmore, A., R.F. Pasquier, and S.L. Olson. 1984. The Birds of the Republic of Panama. Part 4. Passeriformes: Hirundinidae (Swallows) to Fringillidae (Finches). Smithsonian Miscellaneous Collections, Volume 150. Smithsonian Institution Press, Washington, DC, USA. 